\title{
Chemical and nutritional characteristics of different types of DDGS for ruminants*
}

\author{
M. Chrenková, Z. Čerešňáková1，Z. Formelová, M. Poláčiková, \\ Z. Mlyneková and P. Fl'ak \\ Animal Production Research Centre Nitra \\ Hlohovská 2, 95141 Lužianky, Slovak Republic
}

(Received 29 September 2011; revised version 27 June 2012; accepted 29 August 2012)

\begin{abstract}
In this study, different types of cereal grains (maize, wheat, triticale), and their respective distillers dried grains with solubles (DDGS: DDGSM, DDGSW, DDGST) were used. Their effects on parameters expressing nutritional value for ruminants were assessed. The chemical composition of the DDGS was significantly differed $(\mathrm{P}<0.01)$, similarly as that of the cereal grains. The DDGS from maize was the highest in fat $\left(103.5 \mathrm{~g}^{\mathrm{kg}}{ }^{-1} \mathrm{DM}\right)$ but the lowest in crude protein (CP) (291.9 $\left.\mathrm{g} \mathrm{kg}^{-1} \mathrm{DM}\right)$ and ADF (159.9 $\left.\mathrm{gkg}^{-1} \mathrm{DM}\right)$. All DDGS types had similar energy values (ME approx. 12.5 $\mathrm{MJ}^{\mathrm{kg}}{ }^{-1} \mathrm{DM}$, NEL approx. 7.5 $\mathrm{MJ}^{\mathrm{kg}}{ }^{-1} \mathrm{DM}$ and NEV approx. 7.6 $\mathrm{MJ}^{\mathrm{kg}} \mathrm{kg}^{-1} \mathrm{DM}$ ). The DDGS were three times higher in PDIN values than the original grains $(\mathrm{P}<0.01)$. DDGSM had lower in situ effective CP degradability (46.5\%) than DDGSW (58.5\%) and DDGST (76.8\%), but the highest and most stable intestinal digestibility (ID) of rumen undegraded CP $(94.3 \%)$. The most variable intestinal digestibility was found in DDGSW samples (79.6\%-92.2\%). The acid detergent insoluble $\mathrm{CP}$ (ADICP) content (\% from total $\mathrm{CP}$ ) was significantly higher in wheat and triticale DDGS than in the original grains. There were significant plant effects on fat, ME, NEV, ADICP $(\mathrm{P}<0.01), \mathrm{ADF}$, and NADIP $(\mathrm{P}<0.05)$. We can conclude that all types of DDGS are a good source of $\mathrm{CP}$ and energy for ruminants.
\end{abstract}

KEY WORDS: maize, wheat, triticale, DDGS, nutritional value, effective CP degradability, intestinal digestibility

\footnotetext{
* Supported by the Commission of the European Communities, FP7, KBB-2007-1 and by Slovak Ministry of Agriculture, Project RU-0910503-10-16-1000002

${ }^{1}$ Corresponding autor: e-mail: zuzanacer@yahoo.com
} 


\section{INTRODUCTION}

Rapid growth of the bioethanol industry has made large quantities of distillers dried grains with solubles (DDGS) available for use in animal feeding (Kleinschmit et al., 2007). Their variable quality requires systematic evaluation of the nutritional value of different types of DDGS, allowing more precise diet formulation. In Europe the assessment of the nutritive value of DDGS is still under way. DDGS have high feeding values due to their abundance in certain nutritive components and can replace rapeseed meal or soyabean meal as a protein source in diets for dairy cows or growing fattening bulls (Sasikala-Appukuttan et al., 2008; Franke et al., 2009; Meyer et al., 2010). There are many factors that are responsible for the variability in chemical composition and nutritional value of DDGS. The composition and nutritional value of DDGS depend on the cereal grains used (Buenaventura et al., 1987; Rasco et al., 1987; Lee et al., 1991; Akayezu, 1998; Stein et al., 2009; Nuez-Ortín and Yu, 2010a) and on the processing techniques, particularly on the technological conditions (Harty et al., 1998; Knott et al., 2002; Belyea et al., 2004; Berk et al., 2008; Kingsly and Ileleji, 2009).

Existing sophisticated nutrition models (PDI - Vérité et al., 1989; DCE/OEBsystem - Tamminga et al., 1994; NRC, 2001; etc.) for ruminants are able to predict the protein value of feeds and the requirements of animals for ruminally degraded, intestinally digested and absorbed protein. The metabolic characteristics of DDGS protein and energy values are necessary for effective practical exploitation of DDGS in the nutrition of ruminants.

When using DDGS as ruminant feedstuff, attention must be focused chiefly on the quality of CP (such as protein subfractions, in situ CP degradability, intestinal digestibility of rumen undegraded protein, RUP) and their metabolic characteristics.

The objective of this study was to evaluate the effect of various cereal grains on the quality of DDGS produced and to compare the nutritive value of grains and their derived DDGS as feedstuffs for ruminants.

\section{MATERIAL AND METHODS}

\section{Material}

Eighteen samples of bioethanol by-product DDGS (11 samples from maize DDGSM, 5 samples from wheat - DDGSW, 2 samples from triticale - DDGST) and thirteen samples of bioethanol plants ( 6 samples of maize, 4 samples of wheat and 3 samples of triticale) of Slovak and Czech origin were milled on a $1 \mathrm{~mm}$ 
screen for chemical analysis. Samples were analysed for DM, CP, fat, NDF, ADF and ADL according to the Decree of the Ministry of Agriculture of the Slovak Repub. No. 1497/4/1997-100 (1997).

\section{Analysis}

The crude protein profile (soluble $\mathrm{CP}$ (SCP), acid detergent insoluble $\mathrm{CP}$ (ADICP), and neutral detergent insoluble CP (NDICP)) was analysed according to Licitra et al. (1996) in a lower number of samples (5 samples of DDGSM, 2 samples of DDGSW, 2 samples of DDGST, 5 samples of maize, 2 samples of wheat and 3 samples of triticale).

Effective CP degradability and degradation parameters $(a, b, c)$ were determined by the in situ method on three rumen fistulated cows. The animals were fed twice a day with a maintenance diet consisting of $70 \%$ forage and $30 \%$ concentrate on a dry matter basis at maintenance level. The ration consisted of lucerne hay, maize silage, cereal meal (wheat:barley 1:1), mineral and vitamin feed additive. About $4.5 \mathrm{~g}$ of feed samples were ground to pass a $3-\mathrm{mm}$ sieve and weighed into bags $(80 \times 150 \mathrm{~mm})$ made from polyamide cloth, Uhelon $120 \mathrm{~T}$, with a pore size of $47 \mu \mathrm{m}$ (with a minimum of three bags per animal) and incubated for $3,6,9,16$, 24 and $48 \mathrm{~h}$ in the rumen. After incubation the bags were rinsed under cold tap water to remove excess ruminal contents. The bags were washed in a household washing machine without spinning and subsequently dried at $50^{\circ} \mathrm{C}$ for $24 \mathrm{~h}$. Washing losses were determined for $0 \mathrm{~h}$ incubation. The parameters of crude protein degradation and effective degradability were calculated using the Neway programme based on the equations described by Ørskov and McDonald (1979). In the calculation of effective CP degradability an outflow rate of $0.06 \cdot \mathrm{h}^{-1}$ was used. Three cows with permanent T-canulae in the duodenum behind the pancreas were used for the mobile bag method. The undegraded freeze-dried residues after $16 \mathrm{~h}$ ruminal incubation were weighed into small bags of $2.5 \times 4.0 \mathrm{~cm}$ (made from Uhelon 130T with a pore size of $42 \mu \mathrm{m}$ ), incubated in a pepsin - $\mathrm{HCl}$ solution $\left(30 \mathrm{~min}\right.$ at $39^{\circ} \mathrm{C}$ ), and inserted into the duodenum, according to the method described by Straalen and Huisman (1991).

The energy value of bioethanol plants and DDGS was calculated according to the equations for metabolizable energy, ME, net energy of lactation, NEL, net energy of gain, NEV (Sommer et al., 1994); protein values (PDIN and PDIE) were calculated according to the equations of the PDI system (Vérité et al., 1989).

\section{Statistical analysis}

The obtained data were analysed by two-way analysis of variance with 
unequal subclass numbers of observations per cell (Grofík and Fl'ak, 1990) with the Bonferroni multiple comparison test, and by Student's t-test. The statistical software package Statistix 9 was used for the statistical analyses.

\section{RESULTS AND DISCUSSION}

Cereal grains with a high starch content are used in fermentation processes to produce ethanol. The unfermented grain portion with added stillage after drying gives by-products, i.e., dried distillers grains with solubles (DDGS), that have a high fibre content and crude protein that is a good source of rumen undegradable protein (RUP). Many studies (Lee et al., 1991; Harty et al., 1998; Knott et al., 2004; Urdl et al., 2006; Kleinschmit et al., 2007; Nuez-Ortin and Yu, 2009) have shown that DDGS may be highly variable in nutrient content and CP availability. Factors influencing the composition of distillers by-products include the type of grain used, amount of solubles added (Belyea, 1994), and fractionation of particle size (Sosulski et al., 1991; Liu, 2008). Our results showed that chemical composition was significantly different among DDGS types as well as among raw cereal grains (Table 1). Maize DDGS was higher in fat and lower in CP and ADF than wheat and triticale DDGS $(\mathrm{P}<0.01)$. ADL was the highest in triticale DDGS $(\mathrm{P}<0.01)$. A lower content of $\mathrm{CP}, \mathrm{NDF}$ and ADF and higher fat in DDGSM than in DDGSW and DDGST was found (Table 1). The relatively higher content of NDF and ADF in the last two DDGS could be associated with added stillage solubles. According to Lee et al. (1991) wheat stillage solubles contain more fibre (about 3 times) than that from maize. A similar tendency in the concentration of CP, fibre and fat was observed by Lee et al. (1991) in an experiment with maize, durum, and/or spring wheat DDGS. Large variation in total dietary fibre (TDF) content was found (according to the authors, the contents of TDF and NDF should be equivalent) in maize (32\%), wheat (35\%), barley ( $84.7 \%$ ) and sorghum (67.8\%) DDGS (San Buenaventura et al., 1987). Stein et al. (2009) compared 4 samples of maize DDGS that were relatively similar in their CP concentration, however, the concentration of ether extract, ADF, and NDF varied more than $25 \%$ among samples. Franke et al. (2009) in DDGS consisting of $90 \%$ wheat and $10 \%$ barley found a much higher content of NDF (496 g kg-1 DM) and lower content of ADF (159 $\left.\mathrm{g} \mathrm{kg}^{-1} \mathrm{DM}\right)$ than in our DDGSW samples. Spiehs et al. (2002) studied nutrient values of maize DDGS produced from new ethanol plants. They found large variability mainly in NDF and ADF concentrations among and within plants ( $n=118$ samples). Our results are in good agreement with those published data. 
Table 1. Chemical composition of raw cereal grains and derived DDGS, $\mathrm{gkg}^{-1} \mathrm{DM}$

\begin{tabular}{|c|c|c|c|c|c|c|c|}
\hline \multirow{2}{*}{ Nutrient } & & \multicolumn{2}{|c|}{ Maize } & \multicolumn{2}{|c|}{ Wheat } & \multicolumn{2}{|c|}{ Triticale } \\
\hline & & $\bar{x}$ & SEM & $\bar{x}$ & SEM & $\bar{x}$ & SEM \\
\hline \multirow{4}{*}{$\begin{array}{l}\text { Crude } \\
\text { protein }\end{array}$} & Grain & $94.6^{\mathrm{a}}$ & 6.49 & $127.3^{\mathrm{a}}$ & 4.94 & 115.0 & 2.33 \\
\hline & DDGS & $291.9^{\mathrm{ab}}$ & 7.16 & $345.9^{\mathrm{a}}$ & 4.92 & $338.8^{b}$ & 6.36 \\
\hline & $\mathrm{t}$ - test & $* *$ & & $* *$ & & $* *$ & \\
\hline & Grain & $40.7^{\mathrm{ab}}$ & 0.82 & $18.7^{\mathrm{a}}$ & 1.52 & $17.4^{\mathrm{b}}$ & 0.52 \\
\hline \multirow[t]{3}{*}{ Fat } & DDGS & $103.5^{\mathrm{ab}}$ & 6.59 & $44.9^{\mathrm{a}}$ & 2.71 & $46.2^{b}$ & 1.09 \\
\hline & $\mathrm{t}$ - test & $* *$ & & $* *$ & & $*$ & \\
\hline & Grain & 129.2 & 11.33 & 150.7 & 13.87 & 142.6 & 22.97 \\
\hline \multirow[t]{3}{*}{$\mathrm{NDF}$} & DDGS & 377.6 & 19.36 & 372.0 & 32.03 & 390.2 & 3.99 \\
\hline & $\mathrm{t}$ - test & $* *$ & & $* *$ & & $*$ & \\
\hline & Grain & 35.8 & 1.78 & 37.9 & 2.65 & 43.0 & 4.37 \\
\hline \multirow[t]{3}{*}{$\mathrm{ADF}$} & DDGS & $159.9^{a}$ & 7.07 & 217.1 & 34.56 & $269.3^{\mathrm{a}}$ & 1.17 \\
\hline & $\mathrm{t}$ - test & $* *$ & & $* *$ & & ** & \\
\hline & Grain & $13.4^{\mathrm{a}}$ & 1.36 & $9.3^{\mathrm{ab}}$ & 0.24 & $20.5^{\mathrm{ab}}$ & 0.68 \\
\hline \multirow[t]{2}{*}{ ADL } & DDGS & $49.8^{\mathrm{a}}$ & 4.05 & $47.9^{\mathrm{b}}$ & 1.57 & $75.4^{\mathrm{ab}}$ & 0.70 \\
\hline & $\mathrm{t}$ - test & $* *$ & & $* *$ & & $* *$ & \\
\hline \multirow{2}{*}{$\begin{array}{l}\text { Organic } \\
\text { matter }\end{array}$} & Grain & 962.4 & 22.91 & 981.9 & 1.57 & 982.0 & 0.99 \\
\hline & $\begin{array}{l}\text { DDGS } \\
\mathrm{t}-\text { test }\end{array}$ & 951.0 & 4.40 & $\begin{array}{c}938.1 \\
* *\end{array}$ & 4.91 & $\begin{array}{c}947.4 \\
*\end{array}$ & 1.76 \\
\hline
\end{tabular}

means with the same letters in the same row are significantly different; ${ }^{*}$ at $\mathrm{P}<0.05 ;{ }^{* *}$ at $\mathrm{P}<0.01$

In all types of DDGS, the samples contained about 2-4 times more nutrients $(\mathrm{CP}$, fat, $\mathrm{NDF}, \mathrm{ADF}, \mathrm{ADL})$ than the original grains, in agreement with data from the literature (Rasco et al., 1987; Nuez-Ortin and Yu, 2009; Stein et al., 2009), except for the starch concentration, which was much lower (on average for DDGSM $45.4 \mathrm{~g} \cdot \mathrm{kg}^{-1} \mathrm{DM}$, DDGSW $38.5 \mathrm{gkg}^{-1} \mathrm{DM}$, DDGST $37.4 \mathrm{~g} \cdot \mathrm{kg}^{-1} \mathrm{DM}$, respectively) than in grains (Chrenková et al., 2011). Two-way analysis of variance shows significant interaction of original grains $x$ DDGS in fat content $(\mathrm{P}<0.01)$ and ADF content $(\mathrm{P}<0.05)$.

The samples of all types of DDGS had similar energy values that were calculated from the concentration of nutrients determined in this experiment. The ME, NEL and NEV values in DDGS were significantly lower (T-test; $\mathrm{P}<0.01$ or $\mathrm{P}<0.05$ ) than in maize, wheat and/or triticale (Table 2). Similar values of ME and NEL of DDGSW like our (12.1 $\mathrm{MJ}^{\mathrm{kg}}{ }^{-1} \mathrm{DM}$ and $7.4 \mathrm{MJ}^{-1} \mathrm{~kg}^{-1} \mathrm{DM}$, respectively) were determined by Losand et al. (2009) in an experiment with wethers (ME 12.1 MJ $\mathrm{kg}^{-1} \mathrm{DM}$ and $7.3 \mathrm{MJkg}^{-1} \mathrm{DM}$ ) in which various samples of wheat DDGS highly varied in their nutrient concentrations. The lower concentration of energy in DDGS samples was due to the removal of starch in the ethanol production process. Significant differences were found in ME and NEV only among raw cereal grains. As expected, maize was higher $(\mathrm{P}<0.01)$ in $\mathrm{ME}$ and $\mathrm{NEV}$ compared with wheat and triticale, which is due to its higher content of starch and fat. An interaction of raw cereal grains $x$ DDGS was significant for ME and NEV $(\mathrm{P}<0.01)$. 
Table 2. Nutritive values of raw cereal grains and derived DDGS

\begin{tabular}{|c|c|c|c|c|c|c|c|c|c|c|}
\hline \multirow{2}{*}{\multicolumn{2}{|c|}{ Indices }} & \multicolumn{3}{|c|}{ Maize } & \multicolumn{3}{|c|}{ Wheat } & \multicolumn{3}{|c|}{ Triticale } \\
\hline & & $\mathrm{n}$ & $\bar{x}$ & SEM & $\mathrm{n}$ & $\bar{x}$ & SEM & $\mathrm{n}$ & $\bar{x}$ & SEM \\
\hline \multirow{3}{*}{$\begin{array}{l}\text { Metabo- } \\
\text { lizable } \\
\text { energy }\end{array}$} & Grain & 6 & $14.4^{\mathrm{ab}}$ & 0.04 & 4 & $13.3^{\mathrm{a}}$ & 0.03 & 3 & $13.3^{\mathrm{b}}$ & 0.03 \\
\hline & DDGS & 11 & 12.5 & 0.11 & 5 & 12.1 & 0.05 & 2 & 12.29 & 0.05 \\
\hline & $\mathrm{t}-$ test & & ** & & & $* *$ & & & * & \\
\hline \multirow[t]{3}{*}{ NEL } & Grain & 6 & 9.0 & 0.43 & 4 & 8.5 & 0.02 & 3 & 8.5 & 0.02 \\
\hline & DDGS & 11 & 7.66 & 0.071 & 5 & 7.4 & 0.03 & 2 & 7.5 & 0.05 \\
\hline & $\mathrm{t}$ - test & & $*$ & & & $* *$ & & & $*$ & \\
\hline \multirow[t]{2}{*}{ NEV } & Grain & 6 & $10.3^{\mathrm{ab}}$ & 0.05 & 4 & $9.2^{\mathrm{a}}$ & 0.02 & 3 & $9.3^{b}$ & 0.02 \\
\hline & $\begin{array}{l}\text { DDGS } \\
\mathrm{t} \text { - test }\end{array}$ & 11 & 7.8 & 0.09 & 5 & $\begin{array}{l}7.6 \\
* *\end{array}$ & 0.04 & 2 & $\begin{array}{l}7.7 \\
*\end{array}$ & 0.09 \\
\hline \multirow[t]{2}{*}{ PDIE } & Grain & 6 & $124.1^{\mathrm{ab}}$ & 3.17 & 4 & $107.6^{\mathrm{b}}$ & 4.09 & 3 & $92.8^{a}$ & 2.76 \\
\hline & $\begin{array}{l}\text { DDGS } \\
\mathrm{t} \text { - test }\end{array}$ & 11 & $\begin{array}{c}177.8 \\
* *\end{array}$ & 4.93 & 5 & $\begin{array}{c}163.0 \\
*\end{array}$ & 14.32 & 2 & $\begin{array}{c}130.2 \\
*\end{array}$ & 3.02 \\
\hline \multirow[t]{3}{*}{ PDIN } & Grain & 6 & 73.4 & 5.10 & 4 & 82.7 & 4.13 & 3 & 71.0 & 2.19 \\
\hline & DDGS & 11 & 211.1 & 6.34 & 5 & 232.5 & 3.94 & 2 & 220.9 & 2.60 \\
\hline & $\mathrm{T}$ - test & & $* *$ & & & $* *$ & & & $* *$ & \\
\hline
\end{tabular}

means with the same letters in the same row are significantly different; ${ }^{*}$ at $\mathrm{P}<0.05 ;{ }^{* *}$ at $\mathrm{P}<0.01$

As for protein quality, maize DDGS is known as a source of good quality rumen undegraded protein (Owen and Larson, 1991; Harty et al., 1998; NuezOrtin and Yu, 2010b). The results in Table 2 show high values of PDIN in all types of DDGS. Comparison of DDGS and raw cereal grains (T-test) showed that the DDGS were three times higher in PDIN values than the original grains $(\mathrm{P}<0.01)$. No significant differences in PDIN among original grains or among the respective DDGS types were observed. Also no effect of the plant on the protein quality of DDGS was observed.

The very high PDIN values in the DDGS samples can be attributed to their lower rumen effective crude protein degradability (EDCP) and high intestinal digestibility (ID) of RUP (Table 3). The RUP after $16 \mathrm{~h}$ incubation in the rumen was relatively low in DDGST (approx. 30\%), in contrast, it was variable and higher in DDGSM (38.6-49.9\%) and DDGSW (29.7-62.7\%), as also shown by Chrenková et al. (2010). Similar values were observed by Oba et al. (2010) for maize DDGS and triticale DDGS. There were significant differences between bioethanol plants $(\mathrm{P}<0.01)$ and DDGS type $(\mathrm{P}<0.05)$ in EDCP. The highest EDCP (79.5\% and 76.8\%) was found for triticale and DDGST and the lowest for maize and DDGSM (49.6\%, and 46.5\%). The lower EDCP in maize DDGS relative to wheat DDGS was reported also by Nuez-Ortin and Yu (2010a). According to them this is due to the resistance of zein, which is the main maize protein source, to ruminal degradation. EDCP in triticale DDGS (76.8\%) was higher than in wheat DDGS $(58.5 \%)$. The EdCP of wheat DDGS was relatively highly variable $(\mathrm{v}=18 \%)$. 
Table 3. Crude protein effective degradability (EDCP) and intestinal digestibility (ID) of the rumen undegraded crude protein

\begin{tabular}{|c|c|c|c|c|c|c|}
\hline \multirow{3}{*}{$\begin{array}{l}\text { Bioethanol } \\
\text { plant }\end{array}$} & \multicolumn{2}{|c|}{ EDCP, \% } & \multicolumn{4}{|c|}{ ID, \% } \\
\hline & \multirow{2}{*}{ grain } & \multirow{2}{*}{ DDGS } & \multicolumn{2}{|c|}{ grain } & \multicolumn{2}{|c|}{ DDGS } \\
\hline & & & $\bar{x}$ & $\min -\max$ & $\bar{x}$ & $\min -\max$ \\
\hline Maize & $49.6^{\mathrm{ab}}$ & $46.5^{\mathrm{a}}$ & 93.8 & $92.1-95.7$ & 94.33 & $92.8-95.4$ \\
\hline Wheat & $75.6^{\mathrm{a}}$ & $58.5^{\mathrm{b}}$ & 81.6 & $76.4-86.8$ & 88.02 & $79.6-92.2$ \\
\hline Triticale & $79.5^{\mathrm{b}}$ & $76.8^{\mathrm{ab}}$ & 72.6 & $62.3-80.6$ & 87.2 & $85.3-89.0$ \\
\hline
\end{tabular}

means with the same letters in the same column are significantly different at $\mathrm{P}<0.01$

RUP values in maize, wheat and triticale DDGS reported in the literature are highly varied. Harty et al. (1998) presented RUP values of 95 samples of maize DDGS that ranged from 48 to $63 \%$ of CP. The quality of RUP is mainly determined by its digestibility in the small intestine that affects the efficiency of RUP utilization. The intestinal digestibility of RUP and individual amino acids can be highly variable, as shown by our previous results (Chrenková et al., 2010, 2011). Similar high variability of ID was determined in DDGS samples $(\mathrm{n}=95)$ and ranged from 64.2 to $92.2 \%$ (Harty et al., 1998). The variability in crude protein degradability and ID in the case of DDGSw (Figure 1) was not caused by grain species only. These results indicate that various ethanol processing methods (presumably DDGS drying) may affect protein intestinal digestibility and absorbed protein. Previous studies have shown a negative effect of overheating on intestinal digestibility in other feedstuffs (Sommer et al., 1994; Mc Kinnon et al., 1995; Čerešňáková et al., 1996).

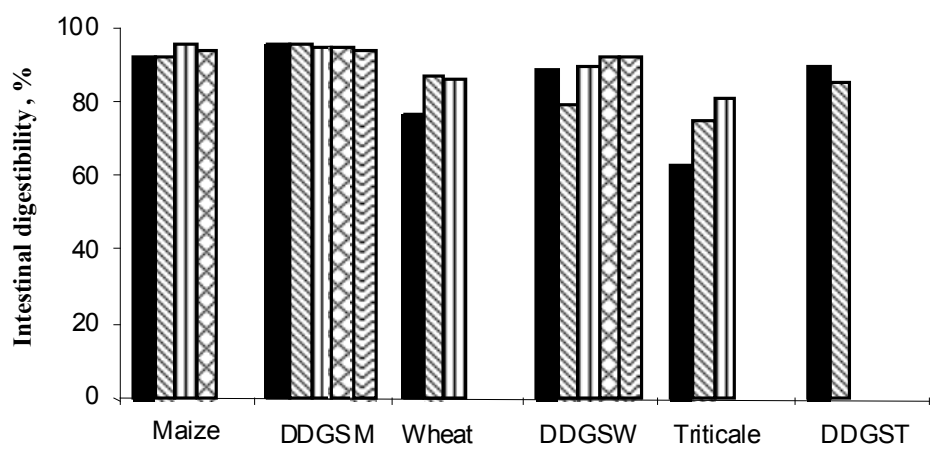

Figure 1. Intestinal digestibility of rumen undegraded CP in individual samples of cereal grains and DDGS types

The differences concerning rumen degraded and intestinally digested protein values were largely associated by differences $(\mathrm{P}<0.01)$ in ADICP (Table 4$)$ between cereal grains and derived DDGS (T-test) and among individual cereal grains and DDGS types $(\mathrm{P}<0.01$ or $\mathrm{P}<0.05)$. Very high ADICP was found in DDGSw 
Table 4. Crude protein and crude protein subfractions of raw cereal grains and derived DDGS

\begin{tabular}{|c|c|c|c|c|c|c|c|}
\hline \multirow{2}{*}{ Indices } & & \multicolumn{2}{|c|}{ Maize } & \multicolumn{2}{|c|}{ Wheat } & \multicolumn{2}{|c|}{ Triticale } \\
\hline & & $\bar{x}$ & SEM & $\bar{x}$ & SEM & $\bar{x}$ & SEM \\
\hline Crude & Grain & $94.60^{\mathrm{a}}$ & 6.49 & $140.42^{\mathrm{ab}}$ & 0.64 & $111.63^{b}$ & 1.03 \\
\hline $\begin{array}{l}\text { protein } \\
\mathrm{gkg}^{-1} \mathrm{DM}\end{array}$ & $\begin{array}{l}\text { DDGS } \\
\mathrm{t} \text { - test }\end{array}$ & $\begin{array}{c}302.88^{\mathrm{a}} \\
* *\end{array}$ & 6.85 & $\begin{array}{c}347.46^{\mathrm{a}} \\
* *\end{array}$ & 2.54 & $\begin{array}{c}321.3^{\mathrm{a}} \\
* *\end{array}$ & 11.06 \\
\hline SCP & Grain & $16.56^{\mathrm{a}}$ & 1.17 & $25.66^{\mathrm{a}}$ & 0.52 & $32.86^{\mathrm{a}}$ & 4.36 \\
\hline$(\%$ of $\mathrm{CP})$ & $\begin{array}{l}\text { DDGS } \\
\mathrm{t} \text { - test }\end{array}$ & $\begin{array}{l}9.63^{\mathrm{a}} \\
*\end{array}$ & 2.45 & $\begin{array}{c}16.08^{\mathrm{a}} \\
* *\end{array}$ & 1.67 & $28.17^{\mathrm{a}}$ & 0.56 \\
\hline NDICP & Grain & $22.20^{\mathrm{ab}}$ & 2.23 & $14.96^{\mathrm{a}}$ & 1.31 & $12.96^{\mathrm{b}}$ & 1.48 \\
\hline$(\%$ of $\mathrm{CP})$ & $\begin{array}{l}\text { DDGS } \\
\mathrm{t} \text { - test }\end{array}$ & $24.11^{\mathrm{a}}$ & 1.53 & $14.54^{\mathrm{a}}$ & 0.94 & $\begin{array}{l}31.72^{\mathrm{a}} \\
* *\end{array}$ & 1.42 \\
\hline ADICP & Grain & $18.70^{\mathrm{ab}}$ & 3.58 & $6.23^{\mathrm{a}}$ & 1.23 & $9.21^{b}$ & $0.30^{\mathrm{a}}$ \\
\hline$(\%$ of $\mathrm{CP})$ & $\begin{array}{l}\text { DDGS } \\
\mathrm{t} \text { - test }\end{array}$ & $16.79^{\mathrm{a}}$ & 1.38 & $\begin{array}{l}22.17^{\mathrm{a}} \\
* *\end{array}$ & 1.05 & $\begin{array}{c}27.91^{\mathrm{a}} \\
* *\end{array}$ & 0.53 \\
\hline
\end{tabular}

means with the same letters in the same row are significantly different; $*$ at $\mathrm{P}<0.05 ; * *$ at $\mathrm{P}<0.01$ SCP- soluble crude protein

(22.17\% of total CP) and in DDGST (27.9\% of total CP). When comparing the wheat and triticale grains and the derived DDGS samples, the later were three times higher in ADICP than the original grains. These results are much higher than the $1.9 \% \mathrm{CP}$ for triticale and 12\% CP for DDGST (Liu, 2012). Ethanol processing also had a significant effect on the soluble fraction of CP in DDGS. Harty et al. (1998) reported high variation for soluble protein ADIP in maize DDGS, probably due to differences in amounts of solubles added and in the heat treatment of DDGS. They also found poor correlation of ADIP with RDP $(r=0.04)$ or with intestinal availability $(\mathrm{r}=-0.28)$. Protein solubility was significantly reduced in DDGS compared with raw cereal grains, except for triticale. Similar results were reported by Nuez-Ortin and Yu (2009). DDGSM was lower $(\mathrm{P}<0.01)$ in SCP ( $9.6 \%$ of total CP) than DDGSW (16.1\% of total CP) and DDGST $(28.2 \%$ of total $\mathrm{CP})$. The main part of soluble $\mathrm{CP}\left(58.3 \mathrm{~g} \mathrm{~kg}^{-1} \mathrm{DM}\right)$ was NAN, with an average of $45.3 \mathrm{~g} \mathrm{~kg}^{-1} \mathrm{DM}$ (data not shown). The crude protein profile was highly varied in raw cereal grains and also in DDGS. Two- way analysis of variance confirmed significant interactions between original grains and DDGS for ADICP $(\mathrm{P}<0.01)$ and for NDICP $(\mathrm{P}<0.05)$.

Analysis of the chemical composition (mainly NDF, ADF, ADICP contents) of native or treated feeds does not fully explain the digestibility of CP. Some studies show that availability of $\mathrm{CP}$ is related to the molecular structure of the protein (Nuez-Ortin and Yu, 2010). Their results showed that the $\alpha$-helix-to- $\beta$-sheet ratio in DDGS proteins had a strongly negative correlation with intestinal digestibility of RUP $(r=-0.95)$. In his study, Liu (2012) compared the DDGS protein molecular structure with the original grain in order to detect structural changes in proteins caused by processing. The amide profiles (the amide I-to-amide II ratio) separated 
from grains and DDGS can be used as a predictor to evaluate protein digestive characteristics.

\section{CONCLUSIONS}

In this study, all types of DDGS proved to be a good source of intestinal digestible (ID) and absorbable protein in the small intestine. The samples of DDGS contained crude protein $(\mathrm{CP})$ with a relatively low effective $\mathrm{CP}$ degradability and low CP solubility. The energy content was significantly higher in DDGS from maize than in that from wheat or triticale. This can be explained by its higher fat content. Although data for all types of DDGS indicate that they are an excellent source of protein and energy, because of their large variability in quality, it is still necessary to determine their nutritional value.

\section{REFERENCES}

Akayezu J.-M., 1998. Use of distillers grains and co-products in ruminant diets. http://www.ddgs. umn.edu/articles-dairy/1998-Akayezu-\%20MNC.pdf

AOAC, 2000. Association of Official Analytical Chemists, Official Methods of Analysis. 17 $7^{\text {th }}$ Edition. Gaithersburg, MD

Belyea R.L., Rausch K.D., Tumbleson M.E., 2004. Composition of corn and distillers grains with solubles from dry grind ethanol processing. Biosource Technol. 94, 293-298. http://www.ddgs. umn.edu/articles-dairy/1998-Akayezu-\%20MNC.pdf

Berk A., Lebzien P., Flachowsky G., 2008. Influence of use of by-products from bio-fuel production in feeds for growing-finishing pigs. In: Proceedings of EAAP - 59 $9^{\text {th }}$ Annual Meeting.Vilnius (Lithuania), p. 265

Bouenaventura M.L., Dong F.M., Rasco B.A., 1987. The total dietary fibre content of wheat, corn, barley, sorghum, and distillers dreid grains with solubles. Cereal Chem. 64, 135-136

Chrenková M., Čerešňáková Z., Formelová Z., Poláčiková M., Fl’ak P., 2011. Effect of raw material for distillers grains production on protein quality for ruminants. J. Life Sci. 5, 814-820

Chrenková M., Čerešňáková Z., Poláčiková M., Formelová Z., Tomíková A., Zaujec S., 2010. Effect of bioethanol co-product type on ruminal degradation and amino acid intestinal digestibility. Slovak J. Anim. Sci. 43, 72-77

Čerešňáková Z., Sommer A., Chrenková M., Poláčiková M., 1996. Crude protein degradability of extruded fullfat soybean in the rumen of ruminants. In: Proceedings of $2^{\text {nd }}$ International Fullfat Soya Conference. Budapest (Hungary), pp. 362-368

Decree of the Ministry of Agriculture of the Slovak Republic, No. 1497/4/1997-100, 1997

Franke K., Meyer U., Flachowsky G., 2009. Distillers dried grain with solubles compared with rapeseed meal in rations of dairy cows. J. Anim. Feed Sci. 18, 601-612

Grofík R., Fl'ak P., 1990, Statistical Methods for Agriculture (in Slovak). Príroda. Bratislava, pp. 344

Harty S.R., Akayezu J.-M., Linn J.G., Cassady J.M., 1998. Nutrient composition of distillers grains with added solubles. J. Dairy Sci. 81, 1201 (Abstr.) 
Kingsly A.R.P., Ileleji K.E., 2009. Sorption isotherm of corn distillers dried grains with solubles (DDGS) and its prediction using chemical composition. Food Chem. 116, 939-946

Kleinschmit D.H., Anderson J.L., Schingoethe D.J., Kalscheur K.F., Hippen A.R., 2007. Ruminal and intestinal degradability of distillers grains plus soluble varies by sources. J. Dairy Sci. 90, 2909-2918

Knott J., Shurson J., Goihl J., 2002. Effects of the nutrient variability of distillers' solubles and grains within ethanol plants and the amount of distillers' solubles blended with distillers' grains on fat, protein and phosphorus content of DDGS. Available:http://www.ddgs.umn. edu/articlesquality/nutrientvariability.pdf. (Accessed January 9, 2005).

Lee W.J., Sosulski F.W., Sokhansanj S., 1991. Yield a composition of soluble and insoluble fraction from corn and wheat stillages. Cereal Chem. 68, 559-569

Licitra G., Hernandez T.M., Van Soest P.J., 1996. Standardization of procedures for nitrogen fractionation of ruminant feeds. Anim. Feed Sci. Tech. 57, 347-358

Liu B., 2012. Indepth study of the relationship between protein molecular structure and the digestive characteristics of the protein in dried distillers grains with solubles. A thesis for the degree of master of science. Department of Animal and Poultry Science. University of Saskatchewan, Saskatoon (Canada), pp. 114

Losand B., Preissinger W., Spiekers H., Urdl M., Gruber L., 2009. Bestimmung der Verdaulichkeit der Rohnährstoffe und des Energiegehaltes von Getreidetrockenschlempeaus Weizenund Weizen-Gerste-Gemischen. Züchtungskunde 81, 173-179

McKinnon J.J., Olubobokun J.A., Mustafa A., Cohen R.D.H., Christensen D.A., 1995. Influence of dry heat treatment of canola meal on site and extent of nutrient disapperance in ruminants. Anim. Feed Sci. Tech. 56, 243-252

Meyer U., Schwabe A., Dänicke S., Flachowsky G., 2010. Effects of by-products from biofuel production on the performance of growing fattening bulls. Anim. Feed Sci. Tech. 161, 132-139

NRC, 2001. Nutrient Requirements of Dairy Cattle. $7^{\text {th }}$ revised Edition. National Academies Press. Washington, DC

Nuez-Ortín W.G., Yu P., 2009. Nutrients variation and availability of wheat DDGS, corn DDGS and blend DDGS from bioethanol plants. J. Sci. Food Agr. 89, 1754-1761

Nuez-Ortín W.G., Yu P., 2010a. Estimation of ruminal and intestinal digestion profiles. hourly effective degradation ratio and potential $\mathrm{N}$ to energy synchronization of co-products from bioethanol processing. J. Sci. Food Agr. 90, 2058-2067

Nuez-Ortín W.G., Yu P., 2010b. Effects of bioethanol plant and coproduct type on the metabolic characteristics of the proteins in dairy cattle. J. Dairy Sci. 93, 3775-3783

Oba M., Penner G.B., Whyte T.D., Wierenga K., 2010. Effects of feeding triticale dried distillers grains plus solubles as a nitrogen source on productivity of lactating dairy cows. J. Dairy Sci. 93, 2044-2052

Owen F.G., Larson L.L., 1991. Corn distillers dried grains versus soybean meal in lactation diets. J. Dairy Sci. 74, 972-979

Ørskov E.R., McDonald I., 1979. The estimation of protein degradability in the rumen from incubation measurements weighted according to rate of passage. J. Agr. Sci. 92, 499-503

Rasco B.A., Dong F.M., Hashisaka A.E., Gazzaz S.S., Downey S.E. Buenaventura M.L., 1987. Chemical composition of distillers dried grains with solubles (DDGS) from soft white wheat, hard wheat and corn. J. Food Sci. 52, 236-237

Sasikala-Appukuttan A.K., Schingoethe D.J., Hippen A.R., Kaischeur K.F., 2008. The feeding value of corn distillers solubles for lactating dairy cows. J. Dairy Sci. 91, 279-287

Sommer A., Chrenková M., Čerešńáková Z., Peisker M., 1994. Einfluss der physikalischen Behandlung von Rapsexpeller, Weizen, Mais und Maiskleberfutter auf die Abbaubarkeit im Pansen und die enzymatische in-vitro Verdaulichkeit des nichtabgebauten Rohproteins. Arch. Anim. Nutr. 46, 207-215 
Sosulski F.W., Lee W.J., Sokhansanj S., 1991. Wet milling and separation of wheat distillers grain with solubles into dietary fiber and protein fractions. Cereal Chem. 68, 562-565

Spiehs M.J., Whitney M.H., Shurson G.C., 2002. Nutrient database for distiller's dried grains with solubles produces from new athanol plants in Minnesota and South Dakota. J. Anim. Sci. 80, 2639-2645

Statistica 9. Copyright 1985-2008. AnalyticalSoftware. Version 9.0

Stein H.H., Connot S.P., Pedersen C., 2009. Energy and nutrients digestibility in four sources of distillers dried grains with solubles produced from corn grown within a narrow geographical area and fed to growing pigs. Asian-Austr. J. Anim. Sci. 22, 1016-1025

Straalen W.M., Huisman G., 1991. The digestibility of bypass crude protein from grass silage in the intestine of dairy cows. Intern rapport IVVO No. 317. Research Institute for Livestock Feeding and Nutrition, Lelystad (The Netherlands), pp. 29

Tamminga S., Straalen W.M., Subnel A.P.J., Meijer R.G.M., Steg A., Wever J.G., Block M.C.,1994. The Dutch protein evaluation system: The DVE/OEB-system. Livest. Prod. Sci. 40, 139-153

Urdl M., Gruber L., Häusler J., Maierhofer G., Schauer A., 2006. Influence of distillers dried grains with solubles (Starprot) in dairy cow feeding. Slovak J. Anim. Sci. 39, 43-50

Vérité R., Journet M., Jarrige R., 1989. A new system for the protein feeding of ruminants: The PDI system. Livest. Prod. Sci. 6, 349-367 